\title{
SPRAWOZDANIE Z KONFERENCJI SEKCJI EMPIRYCZNEJ PEDAGOGIKI RELIGII AKRK
}

DOI: http://dx.doi.org/10.12775/TiCz.2019.021

W dniach 7-9 marca 2019 roku odbyła się XXIII konferencja sekcji pedagogiki empirycznej AKRK (Arbeitsgemeinschaft Katholische Religionspädagogik/Katechetik) w Moguncji w Niemczech. Jej organizatorem $\mathrm{z}$ ramienia AKRK był Christian Höger z Instytutu Teologicznego w Wyższej Szkole Pedagogicznej we Freiburgu. Uczestnicy pochodzili z Niemiec, Austrii, Szwajcarii i Polski.

Konferencja była skierowana dla dwóch typów uczestników. Pierwszego dnia (7 marca) uczestniczyli w niej doktoranci. Dla nich zorganizowano dwa workshopy. Pierwszy prowadził profesor Stefan Altmeyer z Uniwersytetu w Moguncji na temat metody analizy lingwistycznej. Drugi zrealizowała dr Carina Caruso z Uniwersytetu w Kassel na temat „Metody mieszane i triangulacja: różnice, podstawy i podstawowe przykłady ich wykorzystania w ujęciu przeglądowym".

Drugi dzień obrad (8 marca) był skierowany do wszystkich uczestników. W sesji przedpołudniowej miały miejsce trzy wystąpienia. Najpierw Christian Ratzke z Pädagogische Hochschule Freiburg przedstawił wyniki swoich poszukiwań naukowych w zakresie podjętego przez siebie 
tematu badawczego: inicjowanie międzyreligijnego uczenia się poprzez rozwój subkompetencji w wyniku spotkania z przyszłymi nauczycielami etyki i nauczycielami lekcji religii w trakcie edukacji szkolnej. Referent przedstawił założenia badawcze i pierwsze wyniki przeprowadzonych przez siebie badań empirycznych. Rozpoczął najpierw poszukiwania w literaturze naukowej na temat kompetencji. Starał się zrozumieć, jak są one rozumiane w literaturze, jak są zorientowane w lekcji religii, jak spostrzega je pedagogika religijna. Na podstawie tych rozważań starał się określić, czym są kompetencje międzyreligijne oraz jak są one obecne w kształceniu nauczycieli etyki i religii, a na końcu, jak można je ująć empirycznie. Swoje badania prowadził w roku 2016 i 2017. Uczestniczyło w nim 96 studentów zdobywających kwalifikacje do nauczania etyki i lekcji religii z uniwersytetów w Heidelbergu, Karlsruhe, Tubingiem i Wiednia. Wstępne analizy poszukiwań autora wskazują, że studiujący z każdego wyznania przez zajęcia współdziałających ze sobą przedmiotów, dążących do międzyreligijnego uczenia się, mogą przyczyniać się pomniejszenia uprzedzeń religijnych.

Potem dr Boris Kalbheim z Uniwersytetu w Würzburgu mówił o założeniach i wynikach swoich badań w związku z tematem „Kim jestem przed Tobą?” Swoje poszukiwania skoncentrował na problemie badawczym, jak przebiega komunikacja w procesie kształcenia międzyreligijnego. Zauważył, że wiele jest modeli kształcenia międzyreligijnego. To kształcenie jednak napotyka na różne przeszkody będące brakiem takich kompetencji. Ich przejawem jest choćby antysemityzm czy christofobia. Stąd rodzi się kolejne pytanie badawcze: Jak należy postępować, aby uczniowie zdobywali kompetencje do dialogu międzyreligijnego w szkole. W trakcie takich kontaktów dochodzi do dialogu. W tym procesie spotkania ma miejsce oprócz dialogu także opowiadanie o sobie czy o religii. Ważna jest teoria siebie. W wyjaśnieniu tego zagadnienia pomocne jest określenie „diagese” używane przez referującego. Potem dr Boris Kalbheim opisuje wyniki swoich badań w szkołach. W końcowej części podkreślił, że lekcja międzyreligijna daje możliwość uczenia się międzyreligijnego.

Następnie wykład przedstawił ks. dr hab. Kazimierz Skoczylas z Wydziału Teologicznego UMK w Toruniu. Wykładowca przedstawił wyniki badań własnych, prowadzonych wśród młodzieży Kujaw Wschodnich. Scharakteryzował wybrane wartości młodzieży tej części Kujaw 
na przykładzie odniesienia do wartości religijno-moralnych młodzieży Włocławka. Podkreślił dokonujące się stopniowo przemiany w systemie wartości młodego pokolenia Polaków. Zauważył, że stopniowo dokonuje się proces sekularyzacji, który ma wpływ na akceptację wartości religijno-moralnych przekazywanych przez Kościół rzymsko-katolicki w Polsce. To wystąpienie zakończyło sesję przedpołudniową.

Po południu zaplanowano trzy wystąpienia. Najpierw wystąpiła Maria Rehm-Kordesee, potem dr Johannes Heger, a na końcu dr Carina Caruso.

Jako pierwsza w sesji popołudniowej wystąpiła Maria Rehm-Kordese z Ewangelische Hochschule Ludwiksburg. W swoich badaniach zajęła się znaczeniem biografii nauczycieli uczących ewangelickiej i katolickiej lekcji religii dla kształtowania poglądów uczniów na różnorodność religijną. W trakcie badań starała się poznać, jakie znaczenie ma biografia nauczycieli kształtującą ich własną logikę życia dla ich życia i pracy dydaktycznej. Aby to zbadać, posłużyła się metodą wywiadu, poprzez który starała się zrekonstruować logikę własnej biografii. Przez to usiłowała zrekonstruować spojrzenie nauczycieli na zróżnicowanie religii.

Następnie zabrał głos dr Johannes Heger z Wydziału Teologicznego na Uniwersytecie we Freiburgu. Przedstawił założenia i koncepcję badań przyszłej rozprawy habilitacyjnej dotyczącej pojęć eschatologicznych młodzieży. Najpierw autor przedstawił stan badań w teologii w odniesieniu do eschatologii. Następnie dostrzegł istnienie pewnego wzajemnego oddziaływania między pojęciami młodzieży a tradycją wiary. Wskazał też na prace empiryczne odnoszące się do eschatologicznych postaw, zachowań i koncepcji obecnych w świadomości młodzieży. Wymienił między innymi takich autorów zajmujących się tą problematyką, jak: W. Thiede (1991), Kuld (1996/2000), Bescherer 2010, Erdmann 2017.

W literaturze niemieckiej mówi się w tym zakresie o kosmicznej perspektywie eschatologii o pytaniu dotyczącym powszechnej sprawiedliwości, o nadziei, którą rodzi bycie po drugiej stronie. Przeprowadzone poszukiwania $\mathrm{w}$ literaturze naukowej doprowadziły go do zarysowania własnej problematyki badawczej obejmujące następujące pytania: jakie postawy i pojęcia mają młodzi w odniesieniu do uniwersalnych pytań, czy interesują się oni pytaniami i aspektami uniwersalnej eschatologii?, czy rozumieją centralne kościelne i teologiczne wypowiedzi na temat uni- 
wersalnej eschatologii? Autor zaznaczył, że chce przeprowadzić badania ilościowe. Stąd w dalszej kolejności przedstawił swoje narzędzie badawcze. Ponieważ jest to jego autorskie narzędzie, dlatego prosił najpierw uczestników tego spotkania o ocenę swojej ankiety. Podkreślił, że najpierw zamierza przeprowadzić badania pilotażowe, potem poprawić narzędzie i zrealizować badanie na wylosowanej próbie. Po przedstawianiu założeń badawczych uczestnicy sformułowali kilka krytycznych spostrzeżeń w odniesieniu do ankiety. Autor wyraził wdzięczność za celne spostrzeżenia.

Przedmiotem badań dr Cariny Caruso z Uniwersytetu w Koblencji były praktyki szkolne studentów teologii. W ramach studiów dla nauczycieli religii w Niemczech cały semestr przeznaczony jest na praktyki szkolne. Przez nie studenci mają rozwinąć swoje zdolności dydaktyczne. W wyniku odbywania praktyk mają oni osiągnąć pewien poziom profesjonalizacji. Cele stojące przed praktykantami zostały zawarte w dokumentach wydanych przez Konferencję Episkopatu Niemiec. Stąd autorka podjęła problem osiągania profesjonalizacji w pierwszej fazie kształcenia nauczycieli religii. Interesowały ją efekty odbywanej praktyki w odniesieniu do aspektów motywacyjnych, pedagogicznych i dydaktycznych. Przez badania starała się znaleźć odpowiedź, na ile cele określone przez Konferencję Episkopatu Niemiec są osiągane w praktyce pedagogicznej. Badania empiryczne prowadzone przez autorkę skupiły się na zarejestrowaniu rozwoju kompetencji praktykantów, rozwoju kompetencji uczniów katechizowanych przez praktykantów, na aspektach pedagogicznych i dydaktycznych praktyki, przeżyciach obciążających dla nauczycieli powstających $\mathrm{w}$ trakcie praktyki oraz na spostrzeganiu przez praktykantów pedagogicznych efektów swojej praktyki. Wyniki swoich badań potwierdziła przedstawieniem uzyskanych efektów badania $\mathrm{w}$ tabelach $\mathrm{z}$ wynikami badań statystycznych.

W sobotę (9 marca) dr Christian Höger mówił o empirycznych impulsach w badaniu problemu stworzenia człowieka i świata w szkole średniej. Następnie Sarah Delling z Uniwersytetu Siegen przedstawiła komunikat o interakcji i rozwoju tematów na lekcji religii. Po każdym wystąpieniu była podejmowana krótka dyskusja.

Po zrealizowaniu programu konferencji dr Christian Höger dokonał jej podsumowania. Trzeba zauważyć, że każda konferencja stanowi dla pedagogów religii podejmujących problematykę badań empirycznych 
ważne forum wymiany myśli oraz doskonalenia umiejętności metodologicznych. Warto zauważyć, że w krajach obszaru języka niemieckiego przygotowanie habilitacji na niektórych uniwersytetach wymaga przeprowadzenia badań empirycznych związanych z podejmowaną problematyką badawczą i przedstawienie ich wyników w rozprawie habilitacyjnej. Wiele badań empirycznych skupia się na badaniu różnych kompetencji nauczycieli, uczniów czy osób wierzących. 